\title{
THE CONCEPTUAL EVOLUTION IN LINGUISTICS: IMPLICATIONS FOR THE STUDY OF KAAPS
}

\author{
Charlyn Dyers \\ University of the Western Cape
}

\begin{abstract}
As an academic discipline, Linguistics - the scientific study of language - is associated with a range of concepts. Students of Linguistics are traditionally introduced to these concepts in their first year of study, and everything that follows builds on knowledge of these concepts. But language, as Blommaert (2011) notes, is the most visible sign of social change. Currently, much critical thinking is said to be philosophical outflows of a late or post-modern era, characterized by an intensification of three characteristics that have been part of human history for some time: globalization, migration and the dominant position of English, accompanied by the growth of new hybrid languages in urban spaces. In terms of the ongoing vitality of other languages and the influence of a number of dominant language ideologies (Weber and Horner 2012), these three characteristics have sparked discourses of endangerment, revitalization, commodification and carnivalisation (Duchêne en Heller, 2007; Heller, 2010). At the same time, there has been a steady evolution in our understanding of many linguistic concepts, particularly those emanating from particular language ideologies and hierarchical political powers. This paper addresses this issue and its implications for the study and treatment of the colloquial variety of Afrikaans known as Kaaps.
\end{abstract}

Keywords: language ideologies, standardisation, late modernity, social change, and Kaaps

\section{INTRODUCTION AND BACKGROUND}

For most students, the study of Linguistics as an academic discipline initially means coming to grips with the definitions of a wide range of concepts which provide a framework for their understanding of the discipline. But Linguistics is so much greater than the sum of its parts, or its concepts. As the "most visible sign of social change' (Blommaert, 2011), language use mirrors what is happening in our environments and communities. Viewed philosophically, it can be argued the history of mankind appears to have gone through different eras, with names like the Age of Enlightenment, the Industrial Revolution, Modernity and Late or Post-Modernity, all of which have found reflection in people's patterns of language use as well as their attitudes and 
ideologies. Although they may reflect a very bounded and Eurocentric view of history, these different periods serve as a useful framework against which one can consider changing attitudes towards different language varieties.

The current period is labeled by some like Lyotard (1979) as the postmodern era, while others argue that it is simply an extension of modernity and should be called the late modern era (Giddens, 1990). Whatever label one might prefer, it is indisputable that we are currently witnessing the intensification of the following three characteristics of modernity and their influence on language use and the study of Linguistics:

- Globalisation, which Cameron (2001) describes as "the process of integrating and interacting among people and nations politically, economically and culturally". Globalisation is also marked by what Appadurai (1996) describes as "flows" - the flow of people, ideas, money and technology around the world. Of course, globalisation in itself is nothing new in the history of mankind, but the sheer scale of current integration and interaction in real and virtual space has to be acknowledged, together with its influence on language use;

- Migration, which can be translocal as well as transnational, accompanied by the ongoing urbanization of much of humanity. Aronin \& Singleton (2012) provide a figure of 214 million international migrants for the year 2010, but that figure has of course increased significantly in 2015 . Perhaps never before in history have people moved across the world on the scale that we are currently witnessing for diverse reasons: security, a better livelihood, education, escaping dic- tatorships and war, etc.;

- The dominant position of English as international language, which nevertheless has been accompanied by the growth of new hybrid languages especially among urban youth. In this regard, Williams (2010:92-3) writes that globalization and the rise of the knowledge economy has opened up spaces for a new perspective on the relationships between languages. He cites Graddol (2000) who argues that while many of the world's minority languages may die out, there is also an ongoing process of linguistic hybridization which will lead to new language varieties.

The above three characteristics, according to Duchêne and Heller (2007) and Heller (2010) have ignited four particular discourses in relation to the ongoing vitality of languages other than English: discourses of endangerment (e.g. the argument that a culture dies if a language dies); discourses of revitalization (as can be seen through increasing language activism and the use of previously marginalized languages in public signage in e.g. South Africa); discourses of commodification (e.g. the use of indigenous languages in tourism and marketing); and the Bakhtinian notion of carnivalisation (the ludic movement away from conventions, as can be seen in e.g. texting and other forms of on-line discourses). Discourses of endangerment and revitalization are also, to a large degree, embedded in certain dominant language ideologies, which Irvine and Gal (2000:35) define as "the ideas with which participants and observers frame their understanding of linguistic varieties and map those understandings onto people, events, and activities that are significant to them". 
This paper draws attention to the ongoing conceptual evolution taking place in Linguistics, especially sociolinguistics, in which our understanding of the established concepts used to teach the discipline is shifting to much more nuanced definitions in an era where "questions of cultural, religious and personal identity have become acute" (Hassan, 2001:5). While linguistic hybridity is certainly not a new phenomenon, the emergence of new urban codes, especially among the youth, has sparked a lot of interest among sociolinguists like Rampton (1995), Lytra and Jørgensen (2008) and Pennycook (2010). The growing understanding of the role played by linguistic hybridity alongside (and sometimes instead of) the standardized varieties, particularly in the ways people acquire knowledge both formally and informally, is closely related to the changing status of non-standard language varieties like Kaaps. Increasingly, educators are finding innovative ways of using such varieties in the education of children who acquire these hybrid codes from birth (refer in this regard to García, Zakharia and Otcu (eds.) 2013). Even in higher education, hybrid varieties like Kaaps are being used as additional lecture resources for university students (see Antia and Dyers, 2015).

Thus the core question being discussed in this paper is why, in an era marked by mobility and change, a variety like Kaaps should enjoy greater parity of usage with the standard variety of Afrikaans, particularly in the education of children who use this variety as their home and community language. Does it still make sense in late modernity to marginalize the home and community varieties of particular languages as codes for accessing knowledge?

The paper addresses this question by arguing that our understanding of some of the core concepts used to teach Linguistics has changed - i.e. a 'conceptual revolution' has taken place.

\section{WHAT IS KAAPS?}

Three dominant varieties of the Afrikaans language as spoken in South Africa are identified by da Costa, Dyers and Mheta (2014:328): Oosgrens Afrikaans, the variety that was eventually selected for standardization, which was spoken by Dutch settlers in what is now known as the Eastern Cape, Oranjerivier Afrikaans, developed by the speakers of Khoisan languages who came into contact with Dutch in the north-west part of South Africa, and Kaapse Afrikaans (later called Kaaps), initially spoken by the slave population in and around Cape Town.

Kaaps (also known as Cape Vernacular Afrikaans) is a regional and often highly stigmatized variety of Afrikaans, which is one of the official South African languages. It is acknowledged as the variety of Afrikaans most, but by no means exclusively, used by the 'Coloured' people of the Western Cape, particularly in and around the city of Cape Town (Dyers 2008:52-3). In their interesting paper on the use of this variety in a popular local South African newspaper, Blignaut and Lesch (2014:21) list the following key features of Kaaps which distinguish it from other varieties like standard Afrikaans:

- a "substantial English influence" which "includes mixing of English and Afrikaans lexemes, borrowing lexemes from English and the Afrikaansifying of English words";

- a lexicon which also shows "influences from the Muslim community with words like salaam";

- giving existing words "new or extended meanings", e.g. "gevaarlik (dangerous) or duidelik (clear) with the meaning of good or nice"; 
- the use of certain characteristic expressions like "Kom ons [ma:ts] (march) meaning let's go";

- phonological features like "vowel raising, e.g. [uk] (ook); schwa lowering, e.g. [xakom] (gekom); affrication, e.g. [dzəi] (jy) and post-vocalic /r/-deletion, e.g. [vek] (werk)";

- syntactical features including "the use of the definite article die (the) before names of localities and the doubling of in (in) as a preposition and postposition, e.g. Ek bly in die Lavender Hill in"; and

- morphological features like "the embedding of the Afrikaans past tense form (ge-) in the English word, e.g. ge-worry, as well as the redundant addition of post morpheme to adjectives, e.g. bietere".

The following sentence in standard Afrikaans and its equivalent in Kaaps illustrate some of the key differences between these two varieties:

Wanneer laas was jy in Kaapstad vir inkopies? (Standard Afrikaans)

Wanne' laas was djy innie Kaap vi' shopping? (Kaaps)

Translation: When was the last time you went to Cape Town to do some shopping?

For Hendricks (2016, in print) Kaaps, despite these differences, is nonetheless irrevocably part of the total system known as Afrikaans and he argues that acknowledgement of the full spectrum of Afrikaans is part of the ongoing 'democratization of Afrikaans' in the post-apartheid era in South Africa.

\section{THEORETICAL AND CONCEPTUAL FRAMEWORK}

An appropriate theoretical framework for this paper would be what Rampton (1998, in Coupland and Jaworski, 2009:705) calls the sociolinguistics of contact, instead of the more traditional sociolinguistics of community. He argues that socioinguistics has moved on from a concentration on communities in certain spaces/places to a concentration on contact, i.e. what actually happens in language contact situations between speakers of different languages and varieties. This offers a distinct contrast to the language practices of existing speech communities in a country like South Africa traditionally typified by e.g. the Zulu speech community, the Sepedi speech community, the Afrikaans speech community, etc. Indeed, migration and urbanisation is making it far more problematic to identify such speech communities as stable groups with definite norms for language usage. Despite this, the concept of speech communities remains ideologically woven into more conventional approaches to language usage and identity.

Conceptually, this paper draws on the notions of language ideologies, localisation, heteroglossia, hybridity and languaging. In Linguistics there is an increasing understanding that many of the concepts on which the study of the discipline is based, are simply social constructs, which have resulted from particular ideologies as well as the political powers of hierarchy and structuralism. There is an increased awareness that languages, or rather different varieties, exist on linguistic continua (Weber and Horner, 2011), and in many cases it makes little sense to differentiate between different languages like e.g. isiXhosa and isizulu. The 
borders between languages and language varieties on a linguistic continuum, as for example with Standard Afrikaans and Kaaps, are drawn in relation to sociopolitical rather than purely linguistic factors, and in this sense, even languages are social constructs. A key factor in the maintenance of the status quo is the role of language ideologies.

According to Blommaert (2006), the study of language ideologies has developed rapidly as a field in Linguistics since the end of the $20^{\text {th }}$ century, and it is currently seen as of major significance in studies of language use, discourse analysis and language planning. Weber and Horner (2012:16-22) present a clear exposition of existing language ideologies, of which the following three are of direct relevance to this paper:

1. The language hierarchy ideology, according to which language uses can be labelled and divided into 'languages' or 'dialects', 'patois', etc. , with 'languages' enjoying the highest status. Some languages also enjoy a higher status than others when they are labelled national or official languages;

2. The standard language ideology (Milroy and Milroy 1999), which is based on the belief that languages are internally homogenous, bounded entities, with a certain variety chosen for standardisation simply because of socio-political circumstances, and definitely not because of any inherent superiority of these varieties over others; and

3. The ideology of language purism, which stipulates what constitutes 'good' and 'bad' language usage, and often appears in times of rapid social change.

The effect of such ideologies is pervasive and may explain why it is so hard to move from language policies promoting wider multilingualism to the implementation of such policies. In this regard, Dyers and Abongdia (2014:16) argue that "language ideologies may drive more covert policies thereby having an almost paralysing effect on attempts to implement well-intentioned, overt language policies".

But what is currently of greatest significance in sociolinguistics is localisation - what is happening to language at the local, everyday level. In localisation, we see continuous modification, especially to urban varieties, owing to the intense heteroglossia (Bakhtin, 1981) in such spaces. Heteroglossia - an outflow of Bakhtin's work on dialogism - refers to a collection of coexisting 'ways of speaking' - different languages, varieties, styles and registers that are present in different contexts, modalities and media. With reference to the ongoing influence of different linguistic resources in the same space on its speakers, Bhatt (2008:182) talks about linguistic hybridity as a 'third space' between languages and varieties, which:

'gives rise to possibilities for new meanings and at the same time presents a mechanism to negotiate and navigate between a global identity and local practices. It also allows its consumers (readers) to (re-) position themselves with regard to new community practices of speaking and writing.'

Contemporary sociolinguistics therefore supports the view of Heller (2007) and Pennycook (2010) that languages are not autonomous, bounded systems, and that bi/multilingualism should be understood in terms of a more processual and material movement which sees "languages as social practices, speakers as social actors and borders as the product of social 
action” (Heller, 2007). As pointed out by Dyers (2013), language use in e.g. radio discourses, mobile messaging and internet chatrooms provide ample evidence that language choices are not restricted, but that diversity is integrated into such practices, with a concomitant democratization of internet communication leading to a cooperation and celebration of shared cultural and linguistic knowledge and sources.

The beautiful metaphor by McWorther (1998:18, cited in Weber and Horner 2011: 33) of language being like a lava lamp, constantly moving and changing shape, effectively captures the languaging, rather than multilingualism (seen as one bounded language plus others used separately), being practised in urban South Africa. Languaging is defined as "sets of linguistic resources... afforded for language users in different social and cultural circumstances" (Pietikäinen et al. 2008: 81), or how people use their language resources to make meaning, transmit meaning, and enact identities (Blackledge and Creese, 2010:554). Measured against such definitions, a variety like Kaaps is a good example of the 'integrated competence' (Canagarajah andWuhr, 2010: 6) in the different linguistic resources of its speakers.

\section{Which concepts are being questioned?}

The ongoing conceptual evolution in Linguistics has called into question the merits of the continued use of the following concepts in the teaching of Linguistics as an academic discipline:

Mother-tongue - For many people the concept of "mother-tongue" is vital to a sense of cultural preservation and belonging in the world. And while the concept retains its practical social utility and function as an existential resource, my plea here is for the removal of the ideological understanding that a mother tongue 'belongs' to one group. The issue of belonging tends to negate the fact that in multilingual communities, children can have more than one home language (the concept which is increasingly being used in the place of mother-tongue).

First Language, Second Language etc. - the rigidly bounded nature of languages in a multilingual society has little value. It also makes teaching in such languages problematic for teachers who constantly battle to keep first, second and third languages 'pure' and 'separate'. Even the concept 'language' is being questioned, and Abdelhay, Asfaha en Juffermans (2014:vii) argue in favour of 'communicative resource'. Busch however (2012: 521) favours the use of 'repertoire', which "forms a heteroglossic and contingent space of potentialities which includes imagination and desire, and to which speakers revert in specific situations'.

Standard Language versus 'other varieties' - Davies (1991: 59) provides an eminently sensible definition of standardization as a process
"essential for a large complex community which requires the acceptance by everyone of one code as the official means of communication, particularly in education, official business, the professions and the media, both in writing and in public spoken use. The value of the standard language then is that it makes for efficiency, it provides for intelligibility and it avoids uncertainty - what to use in which context and how to spell or say it".

Standardized varieties can certainly not be rejected out of hand owing to their dominance in the fields highlighted 
by Davies. But in South Africa and the rest of Africa the first attempts to produce written versions of the indigenous languages by missionaries and other agencies were usually based on only one regional dialect, which later became Standardized Afrikaans, isiXhosa, Sesotho, and so on. Therefore, like Makoni (2007) and Banda (2010), I contend that there needs to be a greater understanding of the almost arbitrary manner in which certain varieties were chosen for standardization, and suggest that standard varieties should at all times remain open systems, ready to be changed and adapted in accordance with what users are actually doing with language.

Speech community - this concept is too narrowly associated with the onenation one-language ideology as well as with narrowly-defined ethnicities. What does one say to the child of Angolan refugees living in Cape Town, who happens to be a fluent speaker of Kaaps? Sociolinguists like Rampton (1998) and Lanza (2007) prefer the concept of 'Communities of Practice' precisely because the daily interactions of especially urban people do not always bear any relation to dominant assumptions on social identities, positions, groups and hierarchies.

Domains - Fishman's argument (1971) that people use certain languages or varieties in certain domains to the exclusion of others, does not reflect the manner in which urban speakers freely make use of any linguistic resources in their environment, often (but not always) irrespective of the domains within which the interactions are taking place. As an alternative to 'domains', Blommaert, Collins and Slembrouck (2005) suggest the notion of dialogic places which can consist of more than one interactional regime - where the norms for language use are determined by the dominant speakers in a conversation.

$\mathrm{Bi}-$ and multilingualism from a monolingual/monoglot perspective

- there is broad rejection of the one language plus one or many model, as if these languages are never used together in the same sentences or conversations. Canagarajah and Wurr (2011:6) contend that the languages of multilinguals complement each other, and that 'traces of one language on the other are creative, enabling, and offer possibilities for voice'.

Language Shift and Language Death - As languages are open systems, constantly moving and changing instead being of static, bounded systems (Pennycook, 2004:231), language shift is simply a normal process leading to new forms of language diversity. That makes language death a relative concept, as the newer forms always contains elements of the older ones.

It is this ongoing evolution in our understanding of these 'building blocks' of the discipline of Linguistics that will help us to gain much better perspectives on the nature and function of co-existing language varieties like Kaaps and standard Afrikaans.

\section{CONGLUSION}

The broadening and enriching of concepts explaining language repertoires in late modernity must imply that a variety like Kaaps should now be considered in a new light, even by some of its own speakers who profess negative attitudes towards it as a result of the influence of prevailing ideologies. It also implies that the variety, and therefore by implication its speakers, should be accorded the dignity that is its due, especially as it is the oldest variety of Afrikaans. 
The conceptual evolution in Linguistics also has a number of important implications for language planning, policy and implementation. South African provincial and national language policies may emphasize multilingualism, but are in fact based on monolingual models which give no acknowledgement to the linguistic hybridity and languaging of ordinary people, like the speakers of Kaaps. The continued emphasis on standard languages in formal education and language policies in Africa and elsewhere has led to scholars like Banda (2010) pointing out that most people in Africa acquire knowledge without recourse to the standardized (often ex-colonial) languages, which many of them may have not learned through schooling. Together with Makoni and Mashiri (2007), Banda pleads for the inclusion of people's actual language usage in formal education. In Europe, Weber and Horner (2011:132) also call for contextualized language practices in schools, with more flexible double medium and biliterate approaches which build on the complex repertoires so many children bring to school. Starting with the actual language practices of children is probably the best way of making them conscious of the differences between the standard variety and their own, which could assist in helping them to master the standard as well. What is required, as argued by Weber and Horner (ibid.) is the normalization of all forms of multilingualism, without restrictions, at school and in society as a whole.

The often derogatory references to Kaaps as Kombuisafrikaans (Kitchen Afrikaans), 'swartafrikaans' (Black Afrikaans), mengels (Afrikaans mixed with English) and so on does not reflect the linguistic reality of Kaaps as part of a continuum of varieties forming the system called 'Afrikaans'. It reflects the integrated competence of its speakers in the communicative resources they encounter daily. The many public performances and increasing output of literature in Kaaps are indicative of the fact that its users are finding their voice and practising what Stroud (2001) calls linguistic citizenship citizenship pertaining particularly to the role of language and multilingualism as a political resource. This may indicate a growing self-confidence among a previously marginalized group in South Africa, an aspect that should be explored further. But at the same time it needs to be emphasized that Kaaps can be spoken by anyone in close contact with this variety, and that it does not have a rigid association with a particular speech community any longer.

Perhaps the most important implication of the conceptual revolution is that Kaaps should form the linguistic basis for learners who bring it to school as part of their repertoire, and it should be integrated into the language syllabus so that children can come to understand the differences between their own variety and standard Afrikaans. However, this can only be achieved if teachers could change their own negative ideologies towards this variety - particularly the ideologies of language hierarchy and purism. In addition, current language policies should be drastically adapted to free them of a monolingual perspective which allows no room for the hybrid language practices of the late modern urbanite.

The longer it takes to welcome the actual language repertoires of learners to the classroom, the greater the estrangement and even hostility will be between these learners and the standard varieties. By acknowledging what the child brings to the classroom, we strengthen their self-image as their own language 
varieties become integrated into their education.

\section{REFERENGES}

Antia, Bassey and Dyers, Charlyn. 2015. Epistemological access through lecture materials in multiple modes and language varieties: the role of ideologies and multilingual literacy practices in student evaluations of such materials at a South African University. Language Policy, published on-line 31 October 2015, DOI 10.1007/s 10993-015-9389-4.

Bakhtin, Mikhail. 1981. The dialogic imagination. Four essays (edited by M. Holquist; translated by C. Emerson and M. Holquist). Austin: University of Texas Press.

Banda, Felix. 2010. Defying monolingual education: alternative bilingual discourse practices in selected coloured schools in Cape Town. Journal of Multilingual and Multicultural Development 31.3:221-235.

Bhatt, Rakesh. 2008. In other words: Language mixing, identity representations, and third space 1. Journal of Sociolinguistics, 12 (2): 177-200.

Blignaut, Joline. and Lesch, Harold. 2014. 'n Ondersoek na die taalgebruik in Son as verteenwoordigend van Kaaps. Stellenbosch Papers in Linguistics Plus 45:19-41.

Blommaert, Jan. 1996. Language planning as a discourse on language and society: The linguistic ideology of a scholarly tradition. Language Problems and Language Planning 20:199-222.

Blommaert, Jan. 2006. Language ideologies. In K. Brown (ed.) The Encyclopedia of Language and Linguistics, 510-522. Oxford: Elsevier.

Blommaert, Jan. 2011. Truly moving texts. Plenary panel, AILA Mobility, Language, Literacy Conference, Cape Town. January 19, 2011.

Blommaert, Jan., Collins, Jim. and Slembrouck, Stef. (2005a). Spaces of Multilingualism. Language and Communication 25.3, 197-216.
Blommaert, Jan., Collins, Jim. and Slembrouck, Stef (2005b). Polycentricity and interactional regimes in 'global neighbourhoods'. Ethnography 6.2, 205-235.

Busch, Brigitta. 2012. The Linguistic Repertoire Revisited. Applied Linguistics 33.5: 503-523.

Cameron, Deborah. 2001. Current debates on Language and Globalization, Faculty Seminar Fall 2001. Downloaded 11/06/08.

Canagarajah, Suresh. and Wurr, Adrian. 2011. Multilingual Communication and Language Acquisition: New Research Directions. The Reading Matrix 11.1, January 2011.

Creese, Angela. and Blackledge, Adrian. 2010. Towards a sociolinguistics of superdiversity. Published online 15.12.2010. VS Verlag fur Sozialwissenschaften 2010: 449-573.

Davies, Alan. 1991. The Native Speaker in Applied Linguistics. Edinburgh: Edinburgh University Press.

Duchêne, Alexandre. and Heller, Monica. 2007. Discourses of Endangerment. London: Continuum.

Dyers, Charlyn. 2008. Language Shift or Maintenance? Factors Determining the Use of the Afrikaans Language among Some Township Youth in South Africa. Stellenbosch Papers in Linguistics (SPIL) 38: 49-72.

Dyers, Charlyn. 2013. Multilingualism in late-modern Africa: identity, mobility and multivocality. International Journal of Bilingualism, published online, 13 June 2013. DOI: 10.1177/1367006913489203.

Dyers, Charlyn. \& Abongdia, JaneFrancis. 2014. Ideology, policy and implementation: Comparative perspectives from two African universities. Stellenbosch Papers in Linguistics 42:1-16.

Fishman, Joshua. 1972. The Sociology of Language. Rowley: Newbury House.

García, Ofelia, Zakharia, Zeena and Otcu, Bahar. (eds.) 2013. Bilingual Community Education and Multilingualism. Beyond Heritage Languages in a Global City. Bristol: Multilingual Matters. 
Giddens, Anthony. 1990. The Consequences of Modernity. Cambridge: Polity.

Graddol, David. 2000. The Future of English? London: British Council.

Hassan, Ihab. 2001. From Postmodernism to Postmodernity: the Local/Global Context. Philosophy and Literature 25: 1-13 (Spring 2001).

Heller, Monica. (ed.) 2007. Bilingualism: A Social Approach. Basingstoke: Palgrave Macmillan.

Hendricks, Frank. 2016. Die talige aard en konteks van Kaaps: 'n hedendaagse, verledetydse en toekomsperspektief. In F. Hendricks and C. Dyers (eds.) Kaaps in Fokus. Cape Town: SunMedia in print.

Irvine, Judith. and Gal, Susan. 2000. Language Ideology and Linguistic Differentiation. In P. Kroskrity (ed.): Regimes of Language: Ideologies, Polities, and Identity: 35-84. Oxford: American Research Press.

Juffermans, Kasper., Asfaha, Yonas. and Abdelhay, Ashraf. 2014. African Literacies. Ideologies, Scripts, Education. Newcastleupon-Tyne: Cambridge Scholars.

Lanza, Elizabeth. 2007. Multilingualism and the Family. In Peter Auer and Li Wei (eds) Handbook of Multilingualism and Multilingual Communication, pp. 45-68. Berlin: Mouton de Gruyter.

Lyotard, Jean-Franscious. 1979. La Condition postmoderne. Paris: Editions de Minuit.

Lytra, Valley. and Jørgensen, Jens Normann. (eds.) 2008. Multilingualism and Identities Across Contexts. Cross-disciplinary perspectives on Turkish-speaking youth in Europe. Copenhagen Studies in Bilingualism volume 45 . University of Copenhagen, Faculty of the Humanities.

Makoni, Sinfree. \& Mashiri, P. 2007. Critical historiography: Does language planning in Africa need a construct of language as part of its theoretical application? In S. Makoni \& A. Pennycook (eds.) Disinventing and Reconstituting Languages, 62-89. Clevedon: Multilingual Matters.

Martin-Jones, Marlyin. 2014. Foreword of African Literacy: Ideologies, Scripts and
Education (eds.) A. Abdelhay, Y. Asfahah, \& K. Juffermans, page vii. Newcastleupon-Tyne: Cambridge Scholars.

Milroy, James. And Milroy, Leslie. 1999. Authority in Language: Investigating Language Prescription and Standardization. London: Routledge.

Nel, J-M. 2014. Challenges, Opportunities and Possibilities of the implementation of the Language Policy in the Western Cape. Ph.D tesis, Universiteit van Wes-Kaapland.

Pennycook, Alastair. 2004. Language Policy and the ecological turn. Language Policy 3:213-39.

Pennycook, Alastair. 2010. Language as a Local Practice. $1^{\text {st }}$ Ed. New York: Routledge.

Pietikäinen, S., Alanen, R, Dufva, H., Kalaja, P., Leppänen, S., Pitkänen-Huhta, A. 2008. Languaging in Ultima Thule: Multilingualism in the Life of a Sami boy. International Journal of Multilingualism 5.2:79-99.

Rampton, Ben. 1995. Crossing: Language and Ethnicity among Adolescents. London: Longman.

Rampton, Ben. 2009. Speech Community and Beyond. In N. Coupland and A. Jaworski (eds.) The New Sociolinguistic Reader, 694-713. Basingstoke:Palgrave MacMillan.

Stroud, Christopher. 2001. African Mothertongue Programmes and the Politics of Language: Linguistic Citizenship versus Linguistic Human Rights. Journal of Multilingual and Multicultural Development 22.4: 339-355.

Weber, J-J \& Horner, K. 2011. Introducing Multilingualism. A social approach. Abingdon, Oxon: Routledge.

Williams, Glyn. 2010. The Knowledge Economy, Language and Culture. Bristol: Multilingual Matters.

Charlyn Dyers is a professor in the Linguistics Department at the University of the Western Cape (UWC). cdyers@ uwc.ac.za 